\title{
Arachidonic Acid Release and Catecholamine Secretion from Digitonin-Treated Chromaffin Cells: Effects of Micromolar Calcium, Phorbol Ester, and Protein Alkylating Agents
}

\author{
Roy A. Frye and Ronald W. Holz \\ Department of Pharmacology, The University of Michigan Medical School, Ann Arbor, Michigan, U.S.A.
}

\begin{abstract}
The relationship between catecholamine secretion and arachidonic acid release from digitonin-treated chromaffin cells was investigated. Digitonin renders permeable the plasma membranes of bovine adrenal chromaffin cells to $\mathrm{Ca}^{2+}$, ATP, and proteins. Digitonin-treated cells undergo exocytosis of catecholamine in response to micromolar $\mathrm{Ca}^{2+}$ in the medium. The addition of micromolar $\mathrm{Ca}^{2+}$ to digitonin-treated chromaffin cells that had been prelabeled with $\left[{ }^{3} \mathrm{H}\right]$ arachidonic acid caused a marked increase in the release of $\left[{ }^{3} \mathrm{H}\right]$ arachidonic acid. The time course of $\left[{ }^{3} \mathrm{H}\right]$ arachidonic acid release paralleled catecholamine secretion. Although $\left[{ }^{3} \mathrm{H}\right]$ arachidonic acid release and exocytosis were both activated by free $\mathrm{Ca}^{2+}$ in the micromolar range, the activation of $\left[{ }^{3} \mathrm{H}\right]$ arachidonic acid release occurred at $\mathrm{Ca}^{2}+$ concentrations slightly lower than those required to activate exocytosis. Pretreatment of the chromaffin cells with $N$-ethylmaleimide (NEM) or $p$-bromophenacyl bromide (BPB) resulted in dose-dependent inhibition of $10 \mu M \mathrm{Ca}^{2+}$-stimulated $\left[{ }^{3} \mathrm{H}\right]$ arachidonic acid release and exocytosis. The $\mathrm{IC}_{50}$ of
\end{abstract}

NEM for both $\left[{ }^{3} \mathrm{H}\right]$ arachidonic acid release and exocytosis was $40 \mu \mathrm{M}$. The $\mathrm{IC}_{50}$ of $\mathrm{BPB}$ for both events was $25 \mu M$. High concentrations $(5-20 \mathrm{mM})$ of $\mathrm{Mg}^{2+}$ caused inhibition of catecholamine secretion without altering $\left[{ }^{3} \mathrm{H}\right]$ arachidonic acid release. A phorbol ester that activates protein kinase $\mathrm{C}, 12-\mathrm{O}$-tetradecanoylphorbol-13-acetate (TPA), caused enhancement of both $\left[{ }^{3} \mathrm{H}\right]$ arachidonic acid release and exocytosis. The findings demonstrate that $\left[{ }^{3} \mathrm{H}\right]$ arachidonic acid release is stimulated during catecholamine secretion from digitonin-treated chromaffin cells and they are consistent with a role for phospholipase $\mathrm{A}_{2}$ in exocytosis from chromaffin cells. Furthermore the data suggest that protein kinase $C$ can modulate both arachidonic acid release and exocytosis. Key Words: Catecholamine secretion-Arachidonic acid release - Chromaffin cells-Digitonin. Frye R. A. and Holz R. W. Arachidonic acid release and catecholamine secretion from digitonin-treated chromaffin cells: Effects of micromolar calcium, phorbol ester, and protein alkylating agents. $J$. Neurochem. 44, 265-273 (1985).
Exocytosis is a ubiquitous mechanism for the secretion of prepackaged hormones, neurotransmitters, and other substances. The release from cells of the contents of the secretory vesicles by exocytosis was first demonstrated biochemically in early studies of $\mathrm{Ca}^{2+}$-dependent catecholamine secretion from the adrenal medulla (for review, see Viveros, 1975). However, the biochemical events that mediate exocytosis are still largely unknown. Phospholipase $\mathrm{A}_{2}$ (EC 3.1.1.4; phosphatide 2-acylhydrolase) is a $\mathrm{Ca}^{2+}$-dependent enzyme that releases unsaturated fatty acids from the $s n$ - 2-position of phospholipid. Because lysophospholipids (Ahkong et al., 1972) and unsaturated fatty acids such as arachidonic acid (Creutz, 1981) are membrane fusogens, it is possible that this enzyme plays a role in exocytosis. In a previous study we found that stimulation of intact chromaffin cells with a nicotinic cholinergic agonist or by depolarization with elevated $\mathrm{K}^{+}$caused arachidonic acid release that was correlated with catecholamine secretion with regard to time course and $\mathrm{Ca}^{2+}$ dependency (Frye and Holz, 1984). Activation of arachidonic acid release occurs during exocytosis in several other systems
Received April 16, 1984; accepted June 26, 1984.

Address correspondence and reprint requests to Ronald W. Holz, Department of Pharmacology, The University of Michigan Medical School, Ann Arbor, MI 48109, U.S.A.

Abbreviations used: $\mathrm{AA}$, Arachidonic acid; $\mathrm{BPB}, p$-Bromo- phenacyl bromide; BSA, Bovine serum albumin; HEPES, $N$-2Hydroxyethylpiperazine- $N^{\prime}-2$ ethanesulfonic acid; NE, Norepinephrine; NEM, $N$-Ethylmaleimide; PIPES, 1,4-Piperazine diethanesulfonic acid; TPA, 12-O-Tetradecanoylphorbol-13acetate. 
including platelets (Bills et al., 1976), mast cells (Roberts et al., 1979), and pituitary cells (Naor and Catt, 1981).

The plasma membranes of cultured bovine adrenal medullary chromaffin cells can be rendered leaky by digitonin treatment which allows micromolar $\mathrm{Ca}^{2+}$ and ATP in the extracellular medium to enter the chromaffin cells and directly stimulate exocytosis (Dunn and Holz, 1983; Wilson and Kirshner, 1983). The plasma membrane also becomes permeable to proteins. Thus, the preparation allows direct access to the intracellular events occurring during exocytosis. In the present study we have characterized arachidonic acid release from digitonin-treated chromaffin cells and have correlated the release with the exocytosis of catecholamine. The effects of $\mathrm{Ca}^{2+}, \mathrm{Mg}^{2+}$, the phorbol ester 12- $O$-tetradecanoylphorbol-13-acetate (TPA), and the protein alkylating agents $N$-ethylmaleimide (NEM) and $p$-bromophenacyl bromide (BPB) on both arachidonic acid release and exocytosis were investigated.

\section{MATERIALS AND METHODS}

\section{Cell preparation}

Cells disaggregated from bovine adrenal medullae (Fenwick et al., 1978; Kilpatrick et al., 1980) were added to 6.4-mm diameter uncoated culture wells (Costar, Cambridge, MA) at a density of 150,000 cells/well in $0.3 \mathrm{ml}$ of Eagle's minimal essential medium (Gibco, Grand Island, NY) supplemented with $10 \%$ heat-inactivated fetal calf serum (Sterile Systems, Logan, UT), $10 \mu M$ cytosine arabinoside (to inhibit fibroblast proliferation), gentamicin $(50 \mu \mathrm{g} / \mathrm{ml})$, penicillin $(100 \mathrm{U} / \mathrm{ml})$, streptomycin $(100$ $\mu \mathrm{g} / \mathrm{ml}$ ), and Fungizone $(2.5 \mu \mathrm{g} / \mathrm{ml}$ ) (Squibb, Princeton, NJ). In some experiments chromaffin cells were purified by centrifugation through a Percoll density gradient (Kilpatrick et al., 1980) or by differential plating (Waymire et al., 1983). Cortisol released into the culture medium was measured by radioimmune assay. After 4 days at $34^{\circ} \mathrm{C}$ in $5 \% \mathrm{CO}_{2} / 95 \%$ air, chromaffin cells formed monolayers containing approximately $40 \mathrm{nmol}$ catecholamine $/ 10^{6}$ cells. The culture medium was replaced after 4 days and experiments were performed on days 5-10.

\section{Catecholamine secretion}

Cells were incubated for $5 \mathrm{~h}$ with $40 \mu \mathrm{l} /$ well of culture medium described above without cytosine arabinoside containing $0.5 \%(\mathrm{wt} / \mathrm{vol})$ fatty acid-free bovine serum albumin (BSA), $0.5 \mathrm{mM}$ ascorbate, and $1.0 \mu \mathrm{Ci} / \mathrm{ml} l$ $\left[7 .{ }^{3} \mathrm{H}\right]$ norepinephrine (Amersham, Chicago, IL). Cells were then incubated three times for $10 \mathrm{~min}$ with $0.25 \mathrm{ml} /$ well physiological salt solution containing $145 \mathrm{~m} M \mathrm{NaCl}$, $5.6 \mathrm{~m} M \mathrm{KCl}, 2.2 \mathrm{~m} M \mathrm{CaCl}_{2}, 15 \mathrm{~m} M N$-2-hydroxyethylpiperazine- $N N^{\prime}$-2-ethanesulfonic acid (HEPES) (pH 7.4), and $0.5 \%(\mathrm{wt} / \mathrm{vol})$ fatty acid-free BSA.

Experiments were performed at $25^{\circ} \mathrm{C}$. Unless otherwise indicated the cells were incubated for $5 \mathrm{~min}$ with 40 $\mu \mathrm{l}$ of potassium glutamate solution containing $139 \mathrm{mM}$ potassium glutamate, $20 \mathrm{~m} M$ 1,4-piperazirie diethanesulfonic acid (PIPES) (pH 6.6), $1 \mathrm{~m} M \mathrm{MgCl}_{2}, 1 \mathrm{~m} M \mathrm{MgATP}$, $20 \mu M$ digitonin, $0.5 \%$ (wt/vol) fatty acid-free BSA, $5 \mathrm{mM}$
EGTA, and various amounts of $\mathrm{CaCl}_{2}$ to achieve free $\mathrm{Ca}^{2+}$ concentrations calculated according to Portzehl et al. (1964). After removal of the potassium glutamate incubation solution containing the released $\left[{ }^{3} \mathrm{H}\right]$ norepinephrine, the $\left[{ }^{3} \mathrm{H}\right]$ norepinephrine remaining in the cells was liberated by the addition of $40 \mu \mathrm{l}$ of $1 \%$ Triton $\mathrm{X}-100$. The radioactivity in the solutions was measured in a scintillation counter. Catecholamine secretion was expressed as the percentage of the total radioactivity released into the medium.

\section{Arachidonic acid release}

Cells were incubated for $5 \mathrm{~h}$ with $40 \mu \mathrm{l} /$ well of culture medium described above without cytosine arabinoside containing $0.5 \% \mathrm{wt} / \mathrm{vol}$ fatty acid-free BSA and $10 \mu \mathrm{Ci} /$ $\mathrm{ml}\left[5,6,8,9,11,12,14,15-{ }^{3} \mathrm{H}\right]$ arachidonic acid $(100 \mu \mathrm{Ci} /$ mmol) (Amersham, Chicago, IL). [ $\left.{ }^{3} \mathrm{H}\right]$ Arachidonic acidlabeled cells were rinsed three times with physiological salt solution and treated in an identical fashion as $\left[{ }^{3} \mathrm{H}\right]$ norepinephrine-labeled cells as described above. The 40- $\mu \mathrm{l}$ aqueous incubation solution containing the released $\left[{ }^{3} \mathrm{H}\right]$ arachidonic acid was removed from the cells and applied directly to the preadsorbent zone of the TLC plate (Analtech, Newark, DE) which contained $10 \mu \mathrm{g}$ of previously applied nonradioactive arachidonic acid to allow subsequent iodine vapor visualization. Following separation with ethylacetate/acetic acid $(100: 1)$, the arachidonic acid band was scraped and counted to determine released $\left[{ }^{3} \mathrm{H}\right]$ arachidonic acid. Experiments in which ethylacetate extracts of the test solutions were applied to the TLC plates gave identical results. The radioactivity remaining in the cells was solubilized in $1 \%$ Triton X-100 and counted. Results of the $\left[{ }^{3} \mathrm{H}\right]$ arachidonic acid release experiments are expressed as percent of the total radioactivity per well released into the medium as free $\left.{ }^{3} \mathrm{H}\right]$ arachidonic acid.

In experiments in which the distribution of radioactivity in cell lipids was determined, the lipids of the cell monolayer were dissolved in $75 \mu \mathrm{l}$ of jce cold methanol which was added to the well immediately following the removal of the incubation solution. The labeled lipids in the methanol extracts were fractionated by one-dimensional, sequential, ascending TLC. The plates were first run for $15 \mathrm{~min}$ in chloroform/methanol/water (95:35:6). The plates were then run for $25 \mathrm{~min}$ in hexane/diethyl ether/ethanol/ $\mathrm{NH}_{3}(75: 20: 5: 0.5)$. The lipids were separated with the following approximate $R_{\mathrm{f}}$ values: phosphatidylinositol/phosphatidylserine $(0.05)$, phosphatidylcholine $(0.10)$, phosphatidylethanolamine $(0.25)$, arachidonic acid $(0.45)$, diacylglycerol $(0.60)$, and triacylglycerol/cholesterol ester $(0.80)$.

Data are expressed as mean \pm SEM. Error bars smaller than point symbols were omitted from figures. BSA, ATP, TPA, and NEM were purchased from Sigma (St. Louis, MO), BPB from Aldrich (Milwaukee, WI), and digitonin from Fluka (Hauppauge, NY).

\section{RESULTS}

Lipid distribution of radioactivity in $\left[{ }^{3} \mathrm{H}\right.$ ]arachidonic acid-labeled chromaffin cell cultures

The monolayer cultures of bovine chromaffin cells incorporated $\left[{ }^{3} \mathrm{H}\right]$ arachidonic acid primarily 
TABLE 1. $\left[{ }^{3} H\right]$ Norepinephrine secretion and lipid distribution of radioactivity in chromaffin cells labeled with $\left[{ }^{3} \mathrm{H}\right.$ ]arachidonic acid

\begin{tabular}{|c|c|c|c|c|c|c|c|c|}
\hline & $\begin{array}{c}\text { NE } \\
\text { secretion }\end{array}$ & $\begin{array}{c}\text { AA } \\
\text { medium }\end{array}$ & $\begin{array}{l}\text { AA } \\
\text { cell }\end{array}$ & $\begin{array}{l}\mathrm{PC} \\
\text { cell }\end{array}$ & $\begin{array}{l}\mathrm{PE} \\
\text { cell }\end{array}$ & $\begin{array}{c}\mathrm{PI} / \mathrm{PS} \\
\text { cell }\end{array}$ & $\begin{array}{c}\text { TG/CE } \\
\text { cell }\end{array}$ & $\begin{array}{l}\text { DG } \\
\text { cell }\end{array}$ \\
\hline PSS & $\begin{array}{r}2.2 \\
\pm 0.2\end{array}$ & $\begin{array}{r}0.146 \\
\pm 0.012\end{array}$ & $\begin{array}{r}0.226 \\
\pm 0.014\end{array}$ & $\begin{array}{r}39.7 \\
\pm \quad 0.6\end{array}$ & $\begin{array}{r}33.7 \\
\pm 0.5\end{array}$ & $\begin{array}{r}6.4 \\
\pm 0.2\end{array}$ & $\begin{array}{r}19.1 \\
\pm 0.2\end{array}$ & $\begin{array}{r}0.65 \\
\pm 0.01\end{array}$ \\
\hline $\begin{array}{l}\text { Digitonin } \\
\qquad\left(0 \mathrm{Ca}^{2+}\right)\end{array}$ & $\begin{array}{r}2.7 \\
\pm 0.2\end{array}$ & $\begin{array}{r}0.188 \\
+0.003\end{array}$ & $\begin{array}{r}0.212 \\
\pm 0.007\end{array}$ & $\begin{array}{r}38.4 \\
\pm 0.4\end{array}$ & $\begin{array}{r}33.7 \\
\pm \quad 0.2\end{array}$ & $\begin{array}{r}6.6 \\
\pm 0.1\end{array}$ & $\begin{array}{r}20.0 \\
\pm 0.7\end{array}$ & $\begin{aligned} & 0.84^{b} \\
\pm & 0.03\end{aligned}$ \\
\hline $\begin{array}{l}\text { Digitonin } \\
\qquad\left(10 \mu M \mathrm{Ca}^{2+}\right)\end{array}$ & $\begin{array}{r}11.8 \\
\pm 0.3\end{array}$ & $\begin{aligned} & 0.553^{a} \\
\pm & 0.018\end{aligned}$ & $\begin{aligned} & 0.383^{a} \\
\pm & 0.017\end{aligned}$ & $\begin{array}{r}38.1 \\
\pm \quad 0.4\end{array}$ & $\begin{array}{r}33.4 \\
\pm 0.4\end{array}$ & $\begin{array}{r}6.5 \\
+0.1\end{array}$ & $\begin{array}{r}20.2 \\
\pm 0.6\end{array}$ & $\begin{aligned} & 0.98^{c} \\
+ & 0.04\end{aligned}$ \\
\hline
\end{tabular}

Cultured chromaffin cells, which were prelabeled with $\left[{ }^{3} \mathrm{H}\right]$ norepinephrine or $\left[{ }^{3} \mathrm{H}\right]$ arachidonic acid for $5 \mathrm{~h}$, were incubated with physiological salt solution (PSS) or a $20 \mu M$ digitonin-containing potassium glutamate solution with or without $10 \mu M$ free $\mathrm{Ca}^{2+}$. Catecholamine secretion, arachidonic acid release into the medium, and distribution of radioactivity in the indicated cell lipids were determined after 5 min. Lipid results are expressed as percentage of the radioactivity in the indicated lipids. There were four wells/group.

PC, Phosphatidylcholine; PE, phosphatidyl ethanolamine; PI/PS, phosphatidylinositol and phosphatidylserine; TG/CE, triacylglycerol and cholesterol ester; DG, diacylglycerol.

${ }^{a} \mathrm{p}<0.001$ versus digitonin and $0 \mathrm{Ca}^{2+} .{ }^{b} \mathrm{p}<0.001$ versus PSS. ${ }^{c} \mathrm{p}<0.05$ versus digitonin, $0 \mathrm{Ca}^{2+}$.

into the phospholipid pools; however, some of the incorporated radioactivity was associated with a neutral lipid fraction (Table 1). Less than $1 \%$ of the radioactivity associated with the cells was in the form of free $\left[{ }^{3} \mathrm{H}\right]$ arachidonic acid. Treatment of the cells with $20 \mu M$ digitonin in the absence of $\mathrm{Ca}^{2+}$ caused little change in the distribution of $\left[{ }^{3} \mathrm{H}\right]$ arachidonic acid in the cells and a small increase in the amount of $\left[{ }^{3} \mathrm{H}\right]$ arachidonic acid released into the medium. Digitonin treatment in the presence of $10 \mu M$ free $\mathrm{Ca}^{2+}$ caused an almost twofold increase in the level of cell-associated free $\left[{ }^{3} \mathrm{H}\right]$ arachidonic acid and a nearly three-fold increase in the amount of free $\left[{ }^{3} \mathrm{H}\right]$ arachidonic acid released into the medium (Table 1). In the presence of digitonin, $\mathrm{Ca}^{2+}$ caused only a small increase (17 $\pm 5 \%$ ) in the level of labeled diacylglycerol when the rates of $\left[{ }^{3} \mathrm{H}\right]$ arachidonic acid release and catecholamine secretion were maximal (Fig. 1). Because most (about $70 \%$ ) of the $\mathrm{Ca}^{2+}$-dependent $\left[{ }^{3} \mathrm{H}\right]$ arachidonic acid production was released into the medium, in the subsequent experiments only $\left[{ }^{3} \mathrm{H}\right]$ arachidonic acid released into the medium was measured. Therefore the data may somewhat underestimate the total $\mathrm{Ca}^{2+}$-dependent $\left[{ }^{3} \mathrm{H}\right]-$ arachidonic acid produced. In parallel experiments performed under identical conditions with $\left[{ }^{3} \mathrm{H}\right]$ norepinephrine-labeled chromaffin cells, the presence of $10 \mu M \mathrm{Ca}^{2+}$ caused a large increase in catecholamine secretion (Table 1).

In one experiment it was determined that more polar derivatives of $\left[{ }^{3} \mathrm{H}\right]$ arachidonic acid were released from the cells. The radioactivity represented $16 \%$ that of released free $\left[{ }^{3} \mathrm{H}\right]$ arachidonic acid and these compounds were not further investigated.

It is possible that cells such as fibroblasts and adrenal cortical cells that contaminate adrenal medullary chromaffin ceil cultures could contribute to the $\left[{ }^{3} \mathrm{H}\right]$ arachidonic acid release that we observed.
Indeed, digitonin-treated monolayer cultures of bovine adrenal cortical cells labeled with $\left[{ }^{3} \mathrm{H}\right]-$ arachidonic acid released $\left[{ }^{3} \mathrm{H}\right]$ arachidonic acid in response to $10 \mu M \mathrm{Ca}^{2+}$ in a similar manner to that observed with the chromaffin cell cultures (data not shown). However it is unlikely that contaminating cells in the adrenal chromaffin cell cultures were the major source of the released arachidonic acid. Differential plating increases the percentage of chromaffin cells in the preparation from approximately $65 \%$ to at least $95 \%$ as determined by histochemistry and electron microscopy (Waymire et

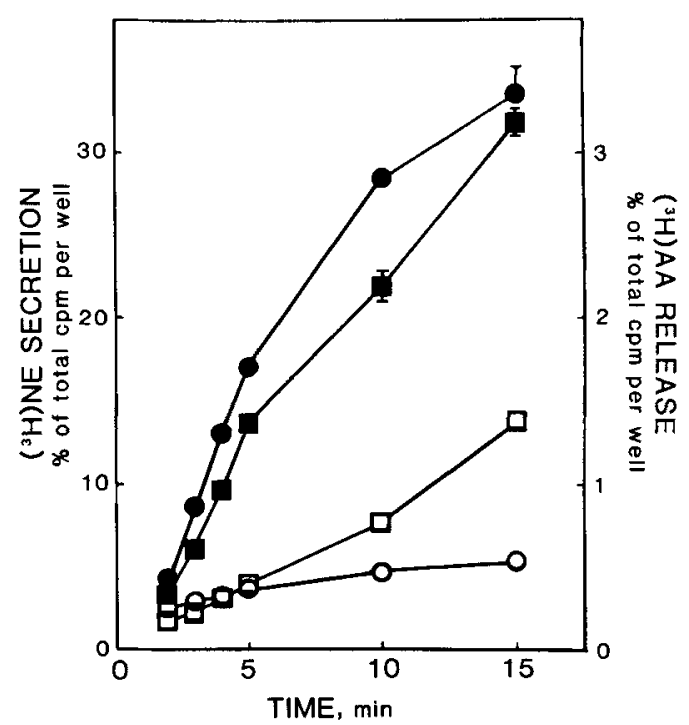

FIG. 1. Time course of arachidonic acid release and exocytosis. Chromaffin cells labeled with $\left[{ }^{3} \mathrm{H}\right]$ norepinephrine or $\left[{ }^{3} \mathrm{H}\right]$ arachidonic acid were incubated for the indicated times with a potassium glutamate solution containing $20 \mu \mathrm{M}$ digitonin in the presence (filled symbois) or absence (open symbols) of $10 \mu \mathrm{M} \mathrm{Ca}^{2+}$. Catecholamine secretion $(0,0)$ and arachidonic acid release $(\square, \square)$ were determined. There were four wells/group. 
al., 1983). Monolayer cultures of these cells had virtually no visually detectable fibroblast-like cells (data not shown). Cortisol secretion into the culture medium, a measure of cortical cell contamination, was reduced by $90 \%$ in monolayers from cells purified by differential plating. The release of $\left[{ }^{3} \mathrm{H}\right]$ arachidonic acid caused by micromolar $\mathrm{Ca}^{2+}$ and the potentiation of release caused by the phorbol esters TPA (see below) were virtually identical in cultures of unpurified chromaffin cells and of these highly purified chromaffin cells (data not shown). Furthermore unpurified cells and cells purified by centrifugation through a Percoll gradient (Fig. 4 for example) also released $\left[{ }^{3} \mathrm{H}\right]$ arachidonic acid in response to micromolar $\mathrm{Ca}^{2+}$ in a similar fashion. Thus arachidonic acid release in cultures of unpurified chromaffin cells is largely accounted for by release from chromaffin cells.

Time course of arachidonic acid release and exocytosis

Chromaffin cell cultures labeled with either $\left[{ }^{3} \mathrm{H}\right]$ norepinephrine or $\left[{ }^{3} \mathrm{H}\right]$ arachidonic acid were incubated with digitonin in the presence or absence of $10 \mu M$ free $\mathrm{Ca}^{2+}$. A slow release of arachidonic acid occurred in the absence of $\mathrm{Ca}^{2+} \cdot \mathrm{Ca}^{2+}(10 \mu M)$ stimulated arachidonic acid release with a similar time course as catecholamine secretion (Fig. 1). $\mathrm{Ca}^{2+}$-stimulated arachidonic acid release and exocytosis occurred most rapidly during the first $5 \mathrm{~min}$.

$\mathrm{Ca}^{2+}$ dose response of arachidonic acid release and exocytosis

Low concentrations of free $\mathrm{Ca}^{2+}$ stimulated both arachidonic acid release and norepinephrine secretion in digitonin-treated cells. The activation of arachidonic acid release occurred at free $\mathrm{Ca}^{2+}$ levels lower than those required to activate exocytosis (Fig. 2). At $1.0 \mu M \mathrm{Ca}^{2+}$ arachidonic acid release was almost fully activated whereas exocytosis was only partially activated. Raising the free $\mathrm{Ca}^{2+}$ concentration from $1.0 \mu M$ to $10 \mu M$ caused a large increase in exocytosis and a much smaller increment in arachidonic acid release (Fig. 2). In a similar experiment (data not shown) $1.0 \mathrm{~m} M$ free $\mathrm{Ca}^{2+}$ caused $60 \%$ greater $\mathrm{Ca}^{2+}$-dependent catecholamine secretion than $10 \mu M \mathrm{Ca}^{2+}$; under the same conditions $1.0 \mathrm{mMCa} \mathrm{Ca}^{2+}$ caused only $28 \%$ greater $\mathrm{Ca}^{2+}$. dependent arachidonic acid release than $10 \mu M$ $\mathrm{Ca}^{2+}$.

\section{Effect of NEM and BPB on arachidonic acid release and exocytosis}

NEM is a nonspecific sulfhydryl alkylating agent that inhibits arachidonate release from platelet membranes (Silk et al., 1981) and catecholamine secretion from digitonin-treated cells (Wilson and Kirshner, 1983). BPB, another protein alkylating agent, inhibits phospholipase $A_{2}$ (Volverk et al.,

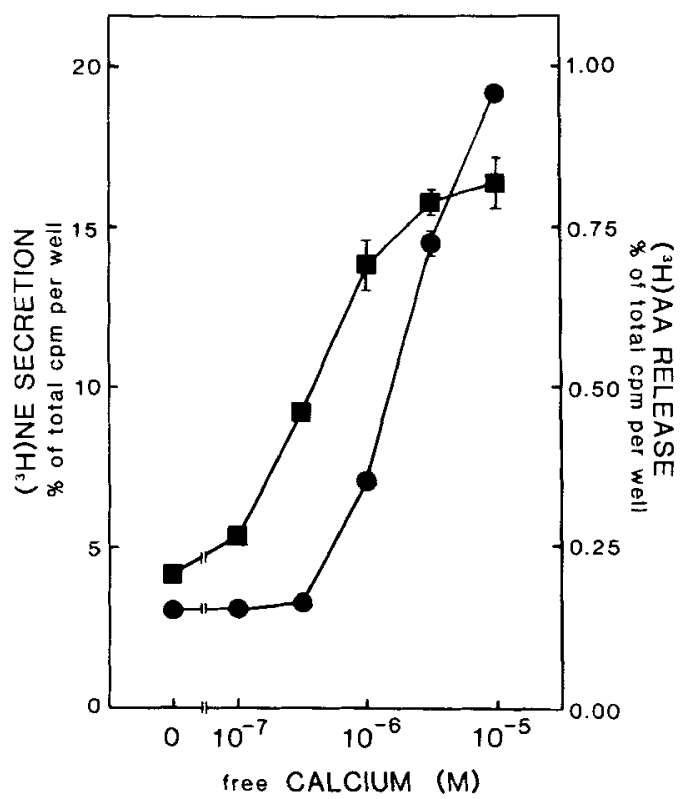

FIG. 2. $\mathrm{Ca}^{2+}$ dose response of arachidonic acid release and exocytosis. Chromaffin cells labeled with $\left[{ }^{3} \mathrm{H}\right]$ norepinephrine or $\left[{ }^{3} \mathrm{H}\right]$ arachidonic acid were incubated with a potassium glutamate solution containing $20 \mu M$ digitonin plus the indicated free $\mathrm{Ca}^{2+}$ concentrations for $5 \mathrm{~min}$. Zero $\mathrm{Ca}^{2+}$ contained $5 \mathrm{mM}$ EGTA and no added $\mathrm{Ca}^{2+}$. Catcholamine secretion $(0)$ and arachidonic acid release (四) were determined after $5 \mathrm{~min}$. There were four welis/group.

1974) and phospholipase C (Hoffman et al., 1982). A comparison was made of the effects of these agents on $\left[{ }^{3} \mathrm{H}\right]$ arachidonic acid release and catecholamine secretion from digitonin-treated cells. Chromaffin cells were incubated for 15 min in physiological salt solution (without BSA) in the presence or absence of the protein alkylating agents and then were incubated in potassium glutamate solution with $20 \mu M$ digitonin in the presence or absence of $10 \mu M \mathrm{Ca}^{2+}$. Pretreatment of chromaffin cells with either agent caused simultaneous inhibition of $\mathrm{Ca}^{2+}$-dependent arachidonic acid release and exocytosis (Fig. 3). Inhibition by NEM of arachidonic acid release and exocytosis occurred between 25 and $100 \mu M\left(\mathrm{IC}_{50}=40 \mu M\right)$, and inhibition by BPB occurred between 10 and $50 \mu M\left(\mathrm{IC}_{50}=25 \mu M\right)$.

Effects of $\mathrm{Mg}^{2+}$ on arachidonic acid release and exocytosis

$\mathrm{Mg}^{2+}$ at high concentrations $(5-20 \mathrm{mM})$ caused a strong inhibition of $\mathrm{Ca}^{2+}$-stimulated catecholamine secretion (Fig. 4). The presence of $20 \mathrm{mM}$ $\mathrm{Mg}^{2+}$ caused a $75 \%$ inhibition of $10 \mu M \mathrm{Ca}^{2+}$-stimulated exocytosis. In contrast $\mathrm{Mg}^{2+}$ had no significant effect on arachidonic acid release. A similar effect of $\mathrm{Mg}^{2+}$ on catecholamine secretion from digitonin-treated chromaffin cells had been previously observed (Wilson and Kirshner, 1983). 

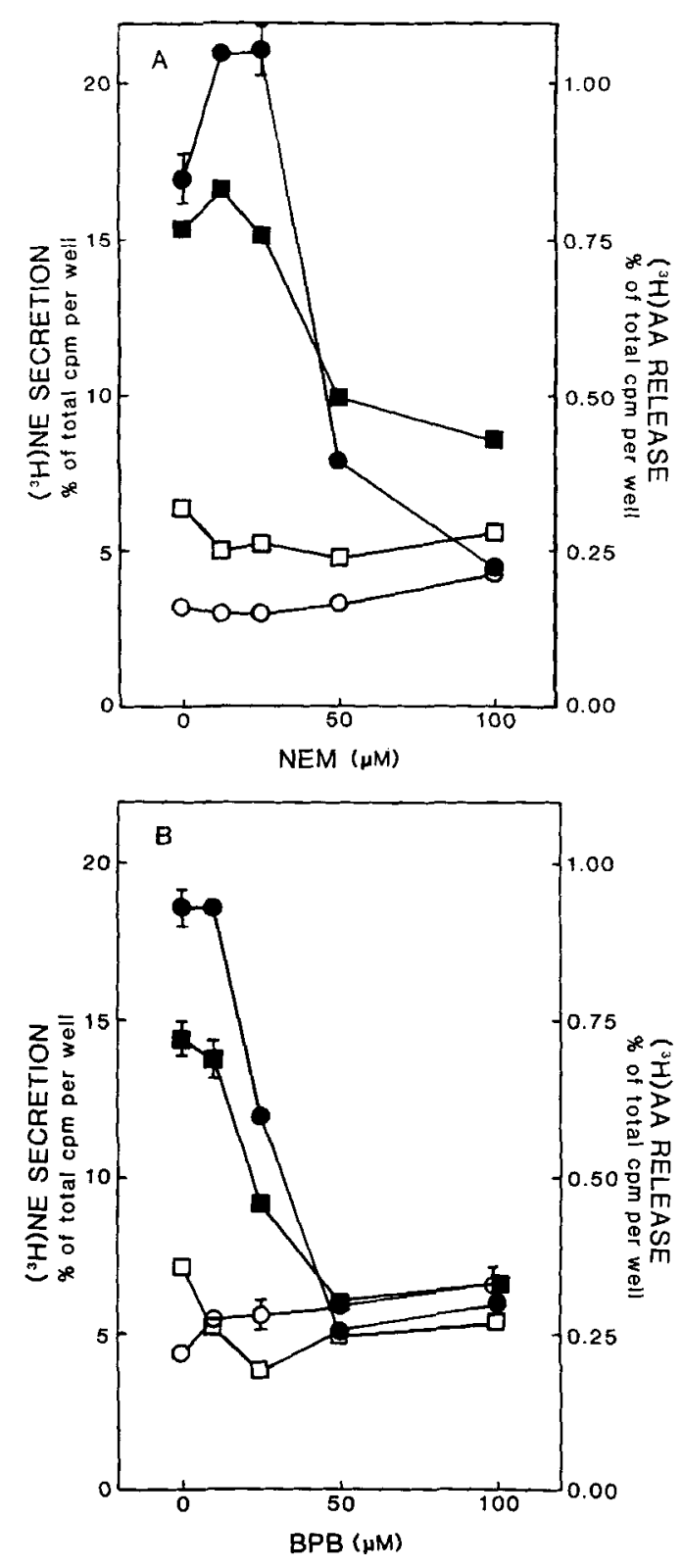

FIG. 3. Effect of NEM and BPB on arachidonic acid release and exocytosis. Chromaffin cells labeled with $\left[{ }^{3} \mathrm{H}\right]-$ norepinephrine or $\left[{ }^{3} \mathrm{H}\right]$ arachidonic acid were incubated for 15 min with physiological salt solution (without BSA) with the indicated concentration of NEM (A) or BPB (B) or solvent control $(0.5 \%$ ethanol). The physiological salt solution was removed and replaced with potassium glutamate solution containing $20 \mu \mathrm{M}$ digitonin in the presence (filled symbols) or absence (open symbols) of $10 \mu \mathrm{M} \mathrm{Ca}^{2+}$. Catecholamine secretion $(\mathbf{0}, 0)$ and arachidonic acid release $(\boldsymbol{\square}, \square)$ were determined after $5 \mathrm{~min}$. There were four wells/group.

\section{Effect of TPA on arachidonic acid release} and exocytosis

The phorbol ester TPA is a direct activator of protein kinase C (Castagna et al., 1982). In platelets activation of protein kinase $\mathrm{C}$ with TPA potentiates the effect of $\mathrm{Ca}^{2+}$ to induce exocytosis (Yamanishi

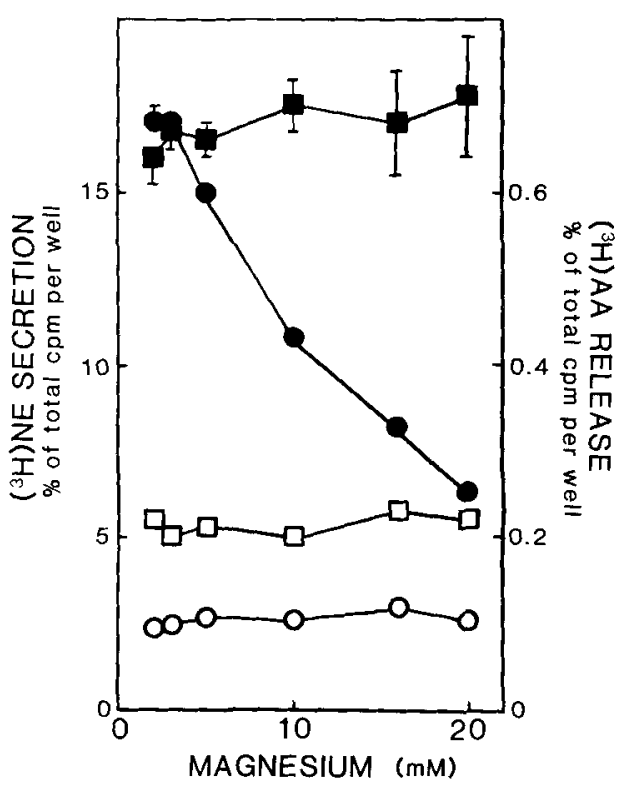

FIG. 4. Effects of $\mathrm{Mg}^{2+}$ on arachidonic acid release and exocytosis. Percoll-purified chromaffin cells labeled with $\left[{ }^{3} \mathrm{H}\right]$ norepinephrine or $\left[{ }^{3} \mathrm{H}\right]$ arachidonic acid were incubated with a potassium glutamate solution containing $20 \mu \mathrm{M}$ digitonin in the presence (filled symbols) or absence (open symbols) of $10 \mu \mathrm{M} \mathrm{Ca}^{2+}$, plus added $\mathrm{Mg}^{2+}$ as indicated. After 5 min, catecholamine secretion $(0,0)$ and arachidonic acid release $(\boldsymbol{\square}, \square)$ were determined. There were four wells/group.

et al., 1983). A similar $\mathrm{Ca}^{2+}$-potentiating effect of TPA on secretion from suspended chromaffin cells rendered leaky by high electric fields has recently been reported (Knight and Baker, 1983). We also observed a stimulation by TPA of exocytosis. We found that pretreatment of the cells with TPA in physiological salt solution was required to give large and reproducible effects (data not shown). Consequently, in the following experiments the cells were pretreated for $15 \mathrm{~min}$ with physiological saline containing the indicated TPA concentrations prior to treatment with the digitonin-containing solution. Treatment of the chromaffin cells with TPA over a range of 10-300 $\mathrm{n} M$ caused a dose-dependent increase in arachidonic acid release and catecholamine secretion (Fig. 5). Treatment with $300 \mathrm{nM}$ TPA increased the $10 \mu M \mathrm{Ca}^{2+}$-stimulated component of arachidonic acid release and exocytosis by 65 and $72 \%$, respectively. A significant stimulation of arachidonic acid release and catecholamine secretion in the absence of $\mathrm{Ca}^{2+}$ was also observed. The effects of various $\mathrm{Ca}^{2+}$ concentrations on catecholamine secretion and arachidonic acid release from digitonin-treated chromaffin cells in the presence and absence of $100 \mathrm{n} M$ TPA were examined (Fig. 6A and B). Catecholamine secretion and arachidonic acid release were significantly increased by TPA between $10^{-7}-10^{-5} M \mathrm{Ca}^{2+}$. Treatment with TPA lowered the threshold concentration of free $\mathrm{Ca}^{2+}$ that was required to activate exocytosis. 


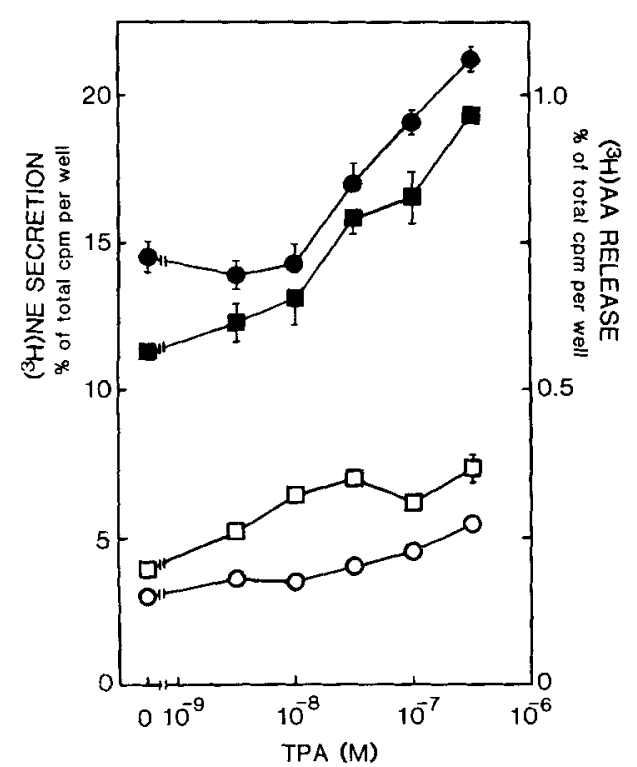

FIG. 5. Stimulation of arachidonic acid release and exocytosis by TPA. Chromaffin cells labeled with $\left[{ }^{3} \mathrm{H}\right]-$ norepinephrine or $\left[{ }^{3} \mathrm{H}\right]$ arachidonic acid were incubated for 15 min with physiological salt solution containing the indicated concentrations of TPA. The solution was then removed and replaced with a potassium glutamate solution containing $20 \mu M$ digitonin in the presence (filled symbols) or absence (open symbols) of $10 \mu M \mathrm{Ca}^{2+}$ and the continued presence of the indicated concentration of TPA. After 5 min catecholamine secretion $(0,0)$ and arachidonic acid release $(\square, \square)$ were determined. There were four wells/group.

The effects of TPA suggest that protein kinase Cmediated protein phosphorylation can modulate arachidonic acid release, and exocytosis and may constitute a potential ATP-requiring step in the process of exocytosis. Chromaffin cells made leaky with digitonin become depleted of cytosolic ATP and become largely dependent upon addition of exogenous ATP for $\mathrm{Ca}^{2+}$-dependent catecholamine secretion (Dunn and Holz, 1983; Wilson and Kirshner, 1983). In some experiments under such ATP-depleted conditions, we have observed a partial ATP dependency for $\mathrm{Ca}^{2+}$-dependent arachidonic acid release (data not shown); however, the effect of ATP on arachidonic acid release has been variable and in other experiments no ATP dependency for arachidonic acid release was observed when catecholamine secretion was stimulated over two-fold by exogenous ATP.

\section{DISCUSSION}

$\mathrm{Ca}^{2+}$-dependent arachidonic acid release from digitonin-treated chromaffin cells

We have previously demonstrated that treatment of chromaffin cells with low concentrations of digitonin renders the plasma membrane permeable to $\mathrm{Ca}^{2+}$, ATP, and proteins and yet preserves the exocytotic release of catecholamine that can be in-
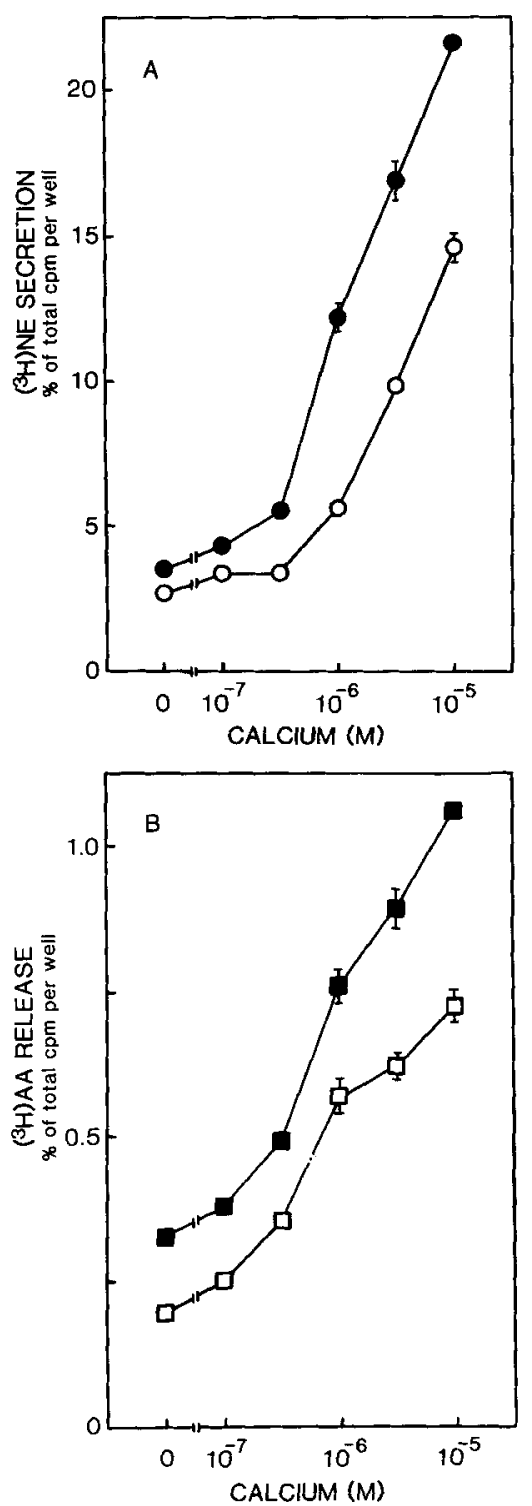

FIG. 6. TPA effect on $\mathrm{Ca}^{2+}$ dose response of exocytosis and arachidonic acid release. Chromaffin cells labeled with $\left[{ }^{3} \mathrm{H}\right]$ norepinephrine or $\left[{ }^{3} \mathrm{H}\right] \mathrm{arachidonic}$ acid were incubated for $15 \mathrm{~min}$ with physiological salt solution in the presence (filled symbols) or absence (open symbols) of $100 \mathrm{nM}$ TPA. The solution was then removed and replaced with a potassium glutamate solution containing $20 \mu M$ digitonin plus the indicated $\mathrm{Ca}^{2+}$ concentration with the same concentration of TPA as in the initial incubation. Catecholamine secretion (A) and arachidonic acid release (B) were determined after $5 \mathrm{~min}$. There were four wells/group. TPA caused statistically significant enhancement of both $\left[{ }^{3} \mathrm{H}\right]$ norepinephrine secretion and arachidonic acid release at all $\mathrm{Ca}^{2+}$ concentrations $(p<0.01)$.

duced by micromolar $\mathrm{Ca}^{2+}$ in the medium (Dunn and Holz, 1983). In this study we have taken advantage of the direct access to the cell interior in digitonin-treated chromaffin cells to study more directly the biochemical events associated with exocytosis. We found that micromolar $\mathrm{Ca}^{2+}$ stimulated 
a three- to five-fold increase in the release of $\left[{ }^{3} \mathrm{H}\right]$ arachidonic acid from prelabelled cellular lipids coincident with catecholamine secretion. The amount of $\left[{ }^{3} \mathrm{H}\right]$ arachidonic acid release was greater than the amount of free $\left[{ }^{3} \mathrm{H}\right]$ arachidonic acid in the cells and, therefore, resulted from the degradation of arachidonic acid-containing lipids, probably either by phospholipase $\mathrm{A}_{2}$ or by activation of phospholipase $\mathrm{C}$ and subsequent activity of diacylglycerol and monoacylglycerol lipase. In platelets there is considerable uncertainty concerning the relative importance of these pathways (Bell et al., 1979; Walenga et al., 1981). Because the latter pathway, if it is important, is associated with a several-fold increase in diacylglycerol (RittenhouseSimmons, 1979) that was not observed in the present experiments, it is likely that phospholipase $A_{2}$ rather than the phospholipase C-diacylglycerol lipase pathway was responsible for $\left[{ }^{3} \mathrm{H}\right]$ arachidonic acid release.

Relationship between $\left[{ }^{3} \mathrm{H}\right]$ arachidonic acid release and catecholamine release from digitonin-treated cells

$\mathrm{Ca}^{2+}$-induced catecholamine secretion was always accompanied by increased $\left[{ }^{3} \mathrm{H}\right]$ arachidonic acid release. $\left[{ }^{3} \mathrm{H}\right]$ Arachidonic acid release was well correlated with catecholamine secretion with regard to time course, inhibition by the two protein-alkylating agents NEM and BPB, and stimulation by the phorbol ester TPA (see below). However $\left[{ }^{3} \mathrm{H}\right]$ arachidonic acid release was activated at a somewhat lower free $\mathrm{Ca}^{2+}$ concentration $(0.3 \mu M)$ than catecholamine secretion (approximately 1 $\mu M) .{ }^{1}$ In addition, 5-20 $\mathrm{mM} \mathrm{Mg}{ }^{2+}$ strongly inhibited $\mathrm{Ca}^{2+}$-dependent catecholamine secretion but had no effect on $\mathrm{Ca}^{2+}$-dependent $\left[{ }^{3} \mathrm{H}\right]$ arachidonic acid release. Thus although arachidonic acid release may be directly involved in secretion, its release was not sufficient to cause secretion.

In previous experiments with intact (untreated with digitonin) chromaffin cells (Frye and Holz, 1984) nicotinic agonist or depolarization by elevated $\mathrm{K}^{+}$caused stimulation of catecholamine secretion that was quantitatively similar to that induced in the present experiments by $10 \mu M \mathrm{Ca}^{2+}$; however $\left[{ }^{3} \mathrm{H}\right]$ arachidonic acid release in intact celis was stimulated only $30 \%$ compared with the three- to fivefold increase caused by $10 \mu M \mathrm{Ca}^{2+}$ in the digitonin-treated chromaffin cells. It is possible that a greater activation of phospholipase $A_{2}$ occurred in

\footnotetext{
' In another system an analogous result has been reported. A basophil-derived cell line undergoes arachidonic acid release and exocytosis when treated with the $\mathrm{Ca}^{2+}$ ionophore $\mathrm{A} 23187$; the level of added $\mathrm{Ca}^{2+}$ needed to activate arachidonic acid release was lower than required to activate exocytosis (McGivney et al., 1981).
}

digitonin-treated chromaffin cells than in intact cells during stimulation. However it is also possible that in the intact cells a large fraction of the free arachidonic acid produced by secretagogue-induced increases in cytosolic $\mathrm{Ca}^{2+}$ concentration was rapidly converted to arachidonyl coenzyme A by arachidonyl coenzyme A synthetase (Wilson et al., 1982; Reddy and Bazan, 1983) and then reincorporated into lipids before it could exit from the cells. In the digitonin-treated cells a much larger fraction of the free arachidonic acid released within cells may have escaped recycling into lipids by rapidly exiting into the medium, perhaps via digitonin-induced holes in the plasma membrane.

In another study we found that BPB inhibited secretion from intact chromaffin cells stimulated by a nicotinic agonist, elevated $\mathrm{K}^{+}$, or $\mathrm{Ba}^{2+}$ (Frye and Holz, 1983). Because BPB also inhibited the $\mathrm{Ca}^{2+}$ uptake associated with the stimulation of secretion, we could not determine if BPB was able to block exocytosis at a point subsequent to $\mathrm{Ca}^{2+}$ influx. However, in other systems (Smolen and Weissman, 1980; Marone et al., 1981) BPB causes an inhibition of $\mathrm{Ca}^{2+}$ ionophore-induced exocytosis that is consistent with our present conclusions, that BPB can inhibit arachidonic acid release and exocytosis at a step subsequent to the increase in cytosolic $\mathrm{Ca}^{2+}$ perhaps by inhibition of phospholipase $A_{2}$ (Volverk et al., 1974).

\section{Effects of the phorbol ester TPA}

TPA is a potent, direct activator of protein kinase C (Castagna et al., 1982; Niedel et al., 1983; Donnelly and Jensen, 1983; Kikkawa et al., 1983). We found that TPA enhanced both arachidonic acid release and exocytosis, especially when present with micromolar $\mathrm{Ca}^{2+}$. Experiments that are currently underway in our laboratory suggest that the effects of phorbol ester on digitonin-treated chromafiin cells are associated with increased protein phosphorylation. The data are consistent with the finding that protein kinase can activate phospholipase in sonicates of macrophages (Wightman et al., 1982). Stimulation of arachidonic acid release by TPA has been observed in other systems (Ohuchi and Levine, 1978; Mufson et al., 1979; Naor and Catt, 1981). One possible mechanism by which TPA could activate arachidonic acid release is by inducing protein kinase $\mathrm{C}$-mediated phosphorylation of lipomodulin (macrocortin), a 40,000-dalton protein. Unphosphorylated, but not phosphorylated, lipomodulin inhibits phospholipase $\mathrm{A}_{2}$ (Hirata et al., 1980; Blackwell et al., 1982; Hirata, 1981).

In summary our experiments with digitonintreated chromaffin cells describe a low micromolar $\mathrm{Ca}^{2+}$ dependency for the activation of cellular arachidonic acid release and demonstrate that arachidonic acid release occurs coincident with cate- 
cholamine secretion. The data support the possibility that phospholipase $A_{2}$ is involved in exocytosis but do not establish a causal relationship. More work is required to characterize the biochemical mechanisms that modulate cellular arachidonic acid release and to determine the relationships of these processes to exocytosis.

Acknowledgments: This work was supported by PHS grant 2-R0-1AM27959 and a grant from the Michigan Heart Association. R.A.F. was a recipient of a Pharmaceutical Manufacturers Association Foundation Advanced Predoctoral Fellowship.

\section{REFERENCES}

Ahkong Q. F., Cramp F. C., Fisher D., Howell J. I., and Lucy J. A. (1972) Studies on chemically induced cell fusion. $J$. Cell Sci. 10, 769-787.

Bell R. L., Kennerly D. A., Stanford N., and Majerus P. W. (1979) Diglyceride lipase: a pathway for arachidonate release from human platelets. Proc. Natl. Acad. Sci. USA 76, $3238-3241$

Blackwell G. J., Carnuccio R., DiRosa M., Flower R. J,, Langham C. S. J., Parente L., Persico P., Russell-Smith N. C., and Stone D. (1982) Glucocorticoids induce the formation and release of anti-inflammatory and anti-phospholipase proteins into the peritoneal cavity of the rat. $B r . J$. Pharmacol. 76, 185-194.

Bills T. K., Smith J. B., and Silver M. J. (1976) Metabolism of $\left[{ }^{14} \mathrm{C}\right]$ arachidonic acid by human platelets. Biochim. Biophys. Acta 424, 303-314.

Castagna M., Takai Y., Kaibuchi K., Sano K., Kikkawa U., and Nishizuka Y. (1982) Direct activation of calcium-activated, phospholipid-dependent protein kinase by tumor promoting phorbol esters. J. Biol. Chem. 257, 7847-7851.

Creutz C. E. (1981) cis-Unsaturated fatty acids induce the fusion of chromaffin granules aggregated by synexin. J. Cell. Biol. 91, 247-256.

Donnelly T. E. and Jensen R. (1983) Effect of fluphenazine on the stimulation of calcium-sensitive phospholipid-dependent protein kinase by 12-O-tetradecanoyl phorbol-13-acetate. Life Sci. 33, 2247-2253.

Dunn L. A. and Holz R. W. (1983) Catecholamine secretion from digitonin-treated adrenal medullary chromaffin cells. J. Biol. Chem. 258, 4989-4993.

Fenwick E. M., Fajdiga P. B., Howe N. S. B., and Livett B. G. (1978) Functional and morphological characterization of isolated bovine adrenal medullary cells. J. Cell. Biol. 76, 12-30.

Frye R. A. and Holz R. W. (1983) Phospholipase $A_{2}$ inhibitors block catecholamine secretion and calcium uptake in cultured bovine adrenal medullary cells. Mol. Pharmacol. 23, $547-550$.

Frye R. A. and Holz R. W. (1984) The relationship between arachidonic acid release and catecholamine secretion from cultured bovine adrenal chromaffin cells. J. Neurochem. 43, $146-150$.

Hirata F. (1981) The regulation of lipomodulin, a phospholipase inhibitory protein in rabbit neutrophils by phosphorylation. J. Biol. Chem. 256, 7730-7733.

Hirata F., Schiffmann E., Venkatasubramanian K., Solomon D., and Axelrod J. (1980) A phospholipase $A_{2}$ inhibitory protein in rabbit neutrophils induced by glucocorticoids. Proc. Natl. Acad. Sci. USA 77, 2533-2536.

Hoffman S. L., Prescott S. M., and Majerus P. W. (1982) The effects of mepacrine and p-bromophenacyl bromide on ar- achidonic acid release in human platelets. Arch. Biochem. Biophys. 215, 237-244.

Kilpatrick D. L., Ledbetter F. H., Carson K. A., Kirshner A. G., Slepetis R., and Kirshner N. (1980) Stability of bovine adrenal medulla cells in culture. $J$. Neurochem. 35, $679-692$.

Kikkawa U., Takai Y., Tanaka Y., Miyake R., and Nishizuka Y. (1983) Protein kinase $C$ as a possible receptor protein of tumor promoting phorbol esters. J. Biol. Chem. 258, 1144211445.

Knight D. E. and Baker P. F. (1983) The phobol ester TPA increases the affinity of exocytosis for calcium in 'leaky' adrenal medullary cells. FEBS Lett. 160, 98-100.

Marone G., Kagey-Sobotka A., and Lichtenstein L. M. (1981) Possible role of phospholipase $A_{2}$ in triggering histamine secretion from human basophils in vitro. Clin. Immunol. Immunopathol. 20, 231-239.

McGivney A., Morita Y., Crews F. T., Hirata F., Axelrod J., and Siraganian R. P. (1981) Phospholipase activation in the IgEmediated and $\mathrm{Ca}^{2+}$ ionophore A23187-induced release of histamine from rat basophilic leukemia cells. Arch. Biochem. Biophys. 212, 572-580.

Mufson R. A., DeFeo D., and Weinstein I. B. (1979) Effects of phorbol ester tumor promoters on arachidonic acid metabolism in chick embryo fibroblasts. Mol. Pharmacol. 16, $569-578$.

Naor Z. and Catt K. J. (1981) Mechanism of action of gonadotropin releasing hormone. Involvement of phospholipid turnover in luteinizing hormone release. J. Biol. Chem. 256, 2226-2229.

Niedel J. E., Kuhn L. J., and Vandenbark G. R. (1983) Phorbol diester receptor copurifies with protein kinase C. Proc. Natl. Acad. Sci. USA 80, 36-40.

nhuchi K. and Levine L. (1978) Stimulation of prostaglandin synthesis by tumor-promoting phorbol-12,13-diesters in canine kidney (MDCK) cells. J. Biol. Chem. 253, 4783-4790.

Portzehl H., Caldwell P. C., and Ruegg J. C. (1964) The dependence of contraction and relaxation of muscle fibres from the crab Maia squinado on the internal concentration of free calcium ions. Biochim. Biophys. Acta 79, 581-591.

Reddy T. S. and Bazan N. G. (1983) Kinetic properties of arachidonoyl-coenzyme $A$ synthetase in rat brain microsomes. Arch. Biochem. Biophys. 226, 125-133.

Rittenhouse-Simmons S. (1979) Production of diglyceride from phosphatidyl inositol in activated human platelets. J. Clin. Invest. 63, 580-587.

Roberts L. J., Lewis R. A., Oates J. A., and Austen K. F. (1979) Prostaglandin, thromboxane, and 12-hydroxy-5,8,10,14eicosatetraenoic acid production by ionophore-stimulated rat serousal mast cells. Biochim. Biophys. Acta 575, 185192.

Silk S. T., Wong K. T. H., and Marcus A. J. (1981) Arachidonic acid releasing activity in platelet membranes: effects of sulfhydryl-modifying reagents. Biochemistry 20, 391-397.

Smith A. D. and Winkler H. (1968) Lysosomal phospholipases $A_{1}$ and $A_{2}$ of bovine adrenal medulla. Biochem. J. 108, $867-874$.

Smolen J. E. and Weissman G. (1980) Effects of indomethacin, $5,8,11,14$-eicosatetraynoic acid, and $p$-bromophenacyl bromide on lysosomal enzyme release and superoxide anion generation by human polymorphonuclear leukocytes. Biochem. Pharmacol. 29, 533-538.

Viveros O. H. (1975) Mechanism of secretion of catecholamines from adrenal medulla, in Handbook of Physiology Endocrinology, Sec. 7, Vol. 6, (Blaschko H., Sayers G., and Smith A. D., eds), pp. 389-426. American Physiological Society, Washington, D.C.

Volverk J. J., Pieterson W. A., and deHaas G. H. (1974) Histidine at the active site of phospholipase $\mathrm{A}_{2}$. Biochemistry 13, $1446-1454$.

Walenga R. W., Opas E. E., and Feinstein M. B. (1981) Differential effects of calmodulin antagonists on phospholipase $\mathrm{A}_{2}$ 
and $\mathrm{C}$ in thrombin-stimulated platelets. J. Biol. Chem. 256, $12523-12528$.

Waymire J. C., Bennett W. F., Boehme R., Hanteins L., GilmerWaymire K., and Haycock J. (1983) Bovine adrenal chromaffin cells: high yield purification and viability in suspension culture. J. Neurosci. Meth. 7, 329-351.

Wightman P. D., Humes J. L., Davies P., and Bonney R. J. (1981) Identification and characterization of 2 phospholipase $\mathrm{A}_{2}$ activities in resident mouse peritoneal macrophages. Biochem. J. 195, 427-433.

Wightman P. D., Dahlgren M. E., and Bonney R. J. (1982) Protein kinase activation of phospholipase $A_{2}$ in sonicates of mouse peritoneal macrophages. J. Biol. Chem. 257, 66506652.

Wilson S. P. and Kirshner N. (1983) Calcium-evoked secretion from digitonin-permeabilized adrenal medullary chromaffin cells. J. Biol. Chem. 258, 4994-5000.

Wilson D. B., Prescott S. M., and Majerus P. W. (1982) Discovery of an arachidonyl coenzyme A synthetase in human platelets. J. Biol. Chem. 257, 3510-3515.

Yamanishi J., Takai Y., Kaibuchi K., Sano K., Castagna M., and Nishizuka Y. (1983) Synergistic functions of phorbol ester and calcium in serotonin release from human platelets. Biochem. Biophys. Res. Commun. 112, 778-786. 